\title{
Diacronie
}

Studi di Storia Contemporanea

$\mathrm{N}^{\circ} 28,4 \mid 2016$

La voce del silenzio

\section{Secret Societies in Japan and Preparation for the Russo-Japanese War (1904-1905)}

\section{Frank Jacob}

\section{(2) OpenEdition}

\section{Journals}

\section{Electronic version}

URL: http://journals.openedition.org/diacronie/4738

DOI: 10.4000/diacronie.4738

ISSN: 2038-0925

\section{Publisher}

Association culturelle Diacronie

\section{Electronic reference}

Frank Jacob, « Secret Societies in Japan and Preparation for the Russo-Japanese War (1904-1905) », Diacronie [Online], $N^{\circ}$ 28, 4 | 2016, document 7, Online since 29 December 2016, connection on 19 April 2019. URL : http://journals.openedition.org/diacronie/4738; DOI : 10.4000/diacronie.4738 


\title{
Diacronie
}

\section{Secret Societies in Japan and Preparation for the Russo-Japanese War (1904-1905)}

\author{
Frank JACOB *
}

The Amur Society (often falsely translated as Black Dragon Society) was a resource for the Japanese military with regard to the preparation of the Russo-Japanese War, but the real impact, as stated in the later publications by members of the society, might be exaggerated. The present article will outline the influence of this right wing secret society related to the preparation of the Russo-Japanese War at the home front and abroad. It will evaluate the actions by the members of the society and try to answer the question, how important a small right wing society could have been for the course of Japan's foreign policy.

\section{Introduction}

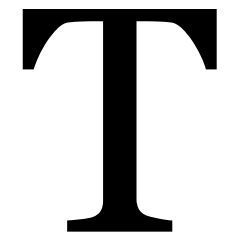

o successfully wage war, one requires military intelligence and adequate preparation for the event itself. While Carl von Clausewitz (1780-1831) had a rather negative view on the value of military intelligence ${ }^{1}$, nowadays it is widely accepted that military intelligence is critical in determining a conflict's outcome ${ }^{2}$. However, not every army has the capacity to gather such information or to prepare a war in any other way, since the importance of such measures has not yet been emphasized in all military forces, even ones active since the end of the 19th century. Japan's military, for instance, is one that has lacked military intelligence services since the late Meiji period (1868-1912). As such, the Japanese

\footnotetext{
${ }^{1}$ CLAUSEWITZ, Carl von, On War, Princeton, NJ, Princeton University Press, 1984, p. 117.

${ }^{2}$ For a criticism of Clausewitz's dogmatic position, see ROSELLO, Victor M., «Clausewitz's Contempt for Intelligence», in Parameters, 21, 1991, pp. 103-114.
} 
Imperial Army had to partly outsource information acquisition and their preparations for the war against Russia in 1904 and 19053. One organization that was highly responsible for this task was the Amur Society (Kokuryūkai)4, a Japanese secret society founded in 1901 by Uchida Ryōhei (1874-1937)5 for the purpose of preparing for war against the Czarist Empire.

The present article will provide insight into the actions of this Japanese secret society and its members, who actively tried to not only provide military intelligence to the military, but also to create or stimulate an anti-Russian sentiment among the Japanese public. Numerous activities in and outside Japan enabled the victories of Japan's expansionist ambitions on the Asian mainland, which would fulfill the destiny of the imperial nation with regard to its supposedly hegemonic role in Asia.

\section{Russo-Japanese Relations Until the Outbreak of the Russo- Japanese War}

When Commodore Matthew C. Perry (1794-1858) forced Japan to open in 1853, the Tokugawa shogunate that had been ruling Japan since 1603 was unable to use their military to counter the United States's demands to open ports on the island's shores. As a consequence, Japan was forcefully integrated into the world system as it had been developing since the $15^{\text {th }}$ century ${ }^{6}$. The shogunate had no choice but to sign a Treaty of Amity and Commerce with the U.S. government, which, in reality, was a euphemistic name for the first of the so-called "unequal treaties" in the country's history7. The

3 JACOB, Frank, Der unkontrollierte Geheimdienst: Die Spionagearbeit geheimer Gesellschaften für das japanische Militär während der Meiji-Zeit, 1868-1912, in MEDROW, Lisa, MÜNZNER, Daniel, RADU, Robert (eds.), Kampf um Wissen. Spionage, Geheimhaltun und Öffentlichkeit 1870-1940, Paderborn, Ferdinand Schöningh, 2015, pp. 179-193.

4 The Japanese name Kokuryūkai is often mistranslated as "Black Dragon Society". The right translation, Amur Society, refers to the society's goal of extending the sphere of Japanese influence on the Asian mainland until the Amur River. Primary works on the Amur Society are JACOB, Frank, Die Thule-Gesellschaft und die Kokuryūkai: Geheimgesellschaften im globalhistorischen Vergleich, Würzburg, Königshausen \& Neumann, 2013; JACOB, Frank, Japanism, Pan-Asianism, and Terrorism: A Short History of the Amur Society (the Black Dragons), 19011945, Bethesda, Academica Press, 2014; SABEY, John Wayne, The Gen'yos̄ha, the Kokuryukai, and Japanese Expansion, Ph.D. Thesis, University of Michigan, 1972.

5 The most accurate biographical work on Uchida is HATSUSE, Ryuhei, Dentoteki uyoku Uchida Ryohei no kenkyü, Fukuoka, Kyūshū Daigaku Shuppankai, 1980.

6 On the world system, see: WALLERSTEIN, Immanuel, World-Systems Analysis: An Introduction, Durham, Duke University Press, 2004.

7 The best English survey of Japan's negotiations with the Western imperialist powers and the role of the unequal treaties is provided by: AUSLIN, Michael R., Negotiating with Imperialism: The Unequal Treaties and the Culture of Japanese Diplomacy, Cambridge, MA, Harvard University Press, 2004. Not only the U.S., but also the powers that would later force Japan into such treaties were highly interested in gaining the status of the "most-favored-nation." See 
foreign pressure, however, not only forced the shogunate to sign treaties with the Western imperialist powers, but also caused Japanese society to transform radically in the Meiji Restoration beginning in 1868. The restoration process would not only reinstate the emperor of Japan as the dominant political power within the country, but also start a tremendous modernization process in all possible sectors of Japanese society. Initially, many foreign hired experts (o-yatoi gaikokujin) were bought to the East Asian island to help realize this transformation ${ }^{8}$. The military, the navy, and Japanese industry were of particular concern for the rulers in Tokyo, who explained their decision to focus on these sectors with the fear of becoming a second China,

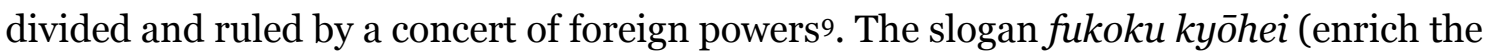
state, strengthen the army) ${ }^{10}$ became emblematic of the early years of Japanese modernization, even if other fields also profited from not only the import of Western knowledge to Japan, but from hired foreigners, who were influential teachers in the early decades of the Meiji period ${ }^{11}$.

However, even if the industrialization of Japan was considered a miracle of the modern period in the nation's history, not everyone agreed on the fast course of modernization and change. Those who suffered from the tremendously fast transformation were the samurai, the military ruling class of the Tokugawa period, whose members became more and more concerned about the Westernization of Japan. The sonnō jōi movement (revere the Emperor, expel the barbarians) gained traction, and anti-restoration forces assembled their strength. Without a fight, they seemed

SHIN'YA, Murase, «The Most-Favored-Nation Treatment in Japan's Treaty Practice During the Period 1854-1905", in The Journal of International Law, 70, 2/1976, pp. 273-297.

8 A good survey of the history of these hired foreigners can be found in UMETANI, Noboru, $O-$ yatoi gaikokujin: Meiji Nihon no wakiyakutachi, Tokyo-, Nihon Keizai Shinbunsha, 1965.

9 Through the contacts to the Dutch in Dejima, the Japanese government was informed about major events in East Asia, especially the Opium Wars that forced China to accept Western supremacy and further stimulated the colonial division of its territory. KOJIMA, Shinji et al., Ahen Senso-kara Shingai Kakumei: Nihonjin no Chōgoku-kan to Chügokujin no Nihon-kan, Tokyo- Toho- Shoten, 1991, ch. 1.

10 While the Japanese navy was formed and trained with the help of British advisors, the military, initially trained by French officers, would later be dominated by a Prusso-German influence. On the Japanese Navy, see EVANS, David C., PEATTIE, Mark R., Kaigun: Strategy, Tactics, and Technology in the Imperials Japanese Navy, 1887-1941, Annapolis, MD, Naval Institute Press, 2012, pp. 1-31. For the development of the Japanese Army, see PRESSEISEN, Ernst Leopold, Before Aggression: Europeans Prepare the Japanese Army, Tucson (AZ), University of Arizona Press, 1965.

11 While Jacob Meckel (1842-1906), a Prussian officer would make important contributions to the military development of the Imperial Japanese Army up until the Russo-Japanese War, many other German specialists were active in other fields in Japan as well. On Meckel's life and work, see KERST, Georg, Jacob Meckel. Sein Leben, sein Wirken in Deutschland und Japan, Göttingen-Zürich-Frankfurt, Musterschmidt, 1970. For a survey of the German case in general, see JACOB, Frank, «Die deutsche Rolle bei der Modernisierung des japanischen Kaiserreiches: zur deutschen Kolonialerfahrung in Japan seit der Eulenburg-Expedition», in Revue d'Allemagne et des Pays de langue allemande, 48, 1/2016, pp. 57-73. 
unwilling to accept the decision of the Meiji government ${ }^{12}$, which did not only have to fight the Boshin War against the shogunate, but also had to deal with samurai uprisings in Japan, with the Satsuma Rebellion in 1877 being among the most famous with SaigoTakamori (1828-1877) as its charismatic leader ${ }^{13}$.

The defeat of these rebels and the establishment of a stable rule in Japan had two major consequences. The forces that had opposed the government organized themselves in secret societies, like the Gen'yōsha (Black Ocean Society) ${ }^{14}$, whose members would try to influence Japanese foreign policy while considering themselves heirs to Saigo $\vec{s}$ legacy. On the other hand, the forcefully unified country of Japan could now focus on its foreign policy, which was aggressive and expansionist, probably perceiving itself as the continuation of Toyotomi Hideyoshi's (1536-1598) attempt to occupy large parts of East Asia during the Imjin War (1592-1598)15. The forced opening of Korea in 1876, just twenty-three years after Japan had been forced to open its ports in the same way, pointed towards the future direction of Japanese expansionist ambitions.

The Sino-Japanese War (1894-1895) could demonstrate that Japan's modernization process had been successful. Within a short period, the small island nation state was able to force China to surrender and sign an unequal treaty with Japan, which would have been granted major indemnities and territorial gains. However, their victory did not go uncontested. The Western powers feared that Japan might gain too much

\footnotetext{
${ }^{12}$ For the struggle between modernizers and those who did not want to support the change regardless of its inaccurate terminology for the Meiji Restoration - see AKAMATSU, Paul, Meiji 1868: Revolution and Counter-Revolution in Japan, New York, Harper \& Row, 1972.

${ }_{13}$ For Saigo- Takamori's ambivalent rule during the transformation process dating from 1868 and the Satsuma Rebellion in 1877, see JACOB, Frank, Nihon: Beiträge zur japanischen Geschichte, New York, ALTIJA, 2016, pp. 26-36. Another example for a samurai rebellion was the Shinpūren Rebellion in 1876. ROGERS, John M., Divine Destruction: The Shinpüren Rebellion of 1876, in HARDCARE, Helen, KERN, Adam L. (eds.), New Directions in the Study of Meiji Japan, vol. 6, Leiden, Brill, 1997, pp. 408-439.

${ }_{14}$ The Kokuryūkai was basically an offshoot of the Gen'yōsha, which had been established in 1881. Some publications have falsely emphasized the influence of the latter right wing secret society on Japan's foreign policy. See TANAKA, Takeyuki, Uchida Ryōhei-ō gojūnensai nensai ni atatte no warera no ketsui to shimei, in TANAKA, Takeyuki (ed.): Uchida Ryōhei-ō gojūnensai tsuiboroku, Tōkyō, Kōgyokusha shuppanbu, 1987, p. 1; WAGNER, Wieland, Japans Außenpolitik in der frühen Meiji-Zeit (1868-1894). Die ideologische und politische Grundlegung des japanischen Führungsanspruchs in Ostasien, Stuttgart, Franz Steiner Verlag, 1990, p. 210. Usually this misconception goes back to one of the influential works on the Black Ocean Society, NORMAN, Egon Herbert, The Gen'yōsha: A Study in the Origins of Japanese Imperialism, in LIVINGSTON, Jon, MOORE, Joe, OLDFATHER, Felicia (eds.), Imperial Japan 180o-1945: The Japan Reader, vol. 1, New York, Pantheon Books, 1973, pp. 355-367. The article was initially published in «Pacific Affairs» in 1944.

${ }^{15}$ The most important book on this war and its East Asian dimensions is SWOPE, Kenneth M., $A$ Dragon's Head and a Serpent's Tail: Ming China and the First Great East Asian War, 15921598, Norman, University of Oklahoma Press, 2016. For the dimensions of the war's impact, see Ibidem, pp. 284-300.
} 
influence in China, especially since the Japanese Empire would have been granted the Liaodong Peninsula as part of the treaty terms. Russia, France, and Germany's socalled Triple Intervention eventually prevented Japan's expansion ${ }^{16}$. The Russian Empire was then seen as dangerous; although Russian diplomatic missions had tried to establish relations with Japan in the mid-19th century, this new act of hostility towards Japanese interests on the Asian mainland could not be tolerated. Regardless of antiRussian sentiments and Japan's anger about Russia's interference - and Germany's, with whom Tokyo- had good relations before - Japan was unable to counter the demands to abdicate its claim to the Liaodong Peninsula, especially since Russia threatened the island state with a naval intervention. The indemnity Japan received from China was consequently invested into the army and navy to prepare for a future war, one that would have to be fought against the Czarist Empire (which would lease Port Arthur, the major military port on the Liaodong Peninsula, after the Triple Intervention).

Russo-Japanese relations would further be worsened by the events related to the Boxer Rebellion in $\mathbf{1 9 0 0}^{17}$. Russian troops occupied Manchuria and thereby threatened Japanese interests in Korea. The Czarist Empire in particular refused to hand back the occupied parts of the region back to China. The border between the Russian-owned territory in the north of Korea, growing imperialist ambitions towards the south. However, this was no official policy of the Russian government, which did not intervene in Korea itself, but the activities of a group, led by Aleksandr Mikhailovich Bezobrazov (1855-1931), which tried to gain several concessions for wood and mining in the north of the peninsula, stimulated the feeling that only a war could prevent Japan's interests on the Korean Peninsula from being taken over by Russian influence all led to the outbreak of the Russo-Japanese War in February $1904^{18}$.

${ }^{16}$ On the role and impact of the Triple Intervention see KOKAZE, Hidemasa, Ajia no teikoku kokka, in KOKAZE, Hidemasa (ed.), Ajia no teikokukokka, Tokyo, Yoshikawa Kobunkan, 2004, pp. 68-70; NISH, Ian, The Anglo-Japanese Alliance. The Diplomacy of Two Island Empires 1894-1907, London-Dover, Athlone Press, 1985, pp. 23-35; NOHARA, Shiro, KOJIMA, Shinji, Yōmu undo'to Nisshin senso, Tokyo, Sanseido-, 1981, pp. 391-399.

17 DABRINGHAUS, Sabine, Die Boxer. Motivation, Unterstützung und Mobilisierung, in LEUTNER, Mechthild, MÜHLHAHN, Klaus (ed.), Kolonialkrieg in China: Die Niederschlagung der Boxerbewegung 1900-1901, Berlin, Ch. Links Verlag, 2007, pp. 60-61; MÜHLHAHN, Klaus, China als Halbkolonie. Die kolonialen Stützpunkte und Pachtgebiete der europäischen Staaten, in LEUTNER, Mechthild, MÜHLHAHN, Klaus (ed.), op. cit., p. 31.

${ }^{18}$ For a recent and critical discussion about Russia's responsibility for the Japanese attack see WADA, Haruki, Nichiro senso: Kigen to kaisen, 2 voll., Tokyo, Iwanami Shoten, 2009-2010. For the role of Bezobrazov and his group see LUKOIANOV, Igor V., The Bezobrazovtsky, in STEINBER, John et al. (ed.), The Russo-Japanese War in Global Perspective. World War Zero, vol. 1, Leiden-Boston, Brill, 2005, pp. 65-86. 
Due to the events in 1900, Uchida Ryōhei, who had already been sent to Korea in 1894 with a group of Japanese saboteurs to provoke war with China ${ }^{19}$ and who had traveled through the Russian Far East in the late $1800 \mathbf{s}^{20}$, considered Russia the most dangerous enemy for the expansionist success of Japan. He therefore founded the Amur Society in 1901 to prepare his fellows and Japanese society alike for the war against the Czarist Empire. The Society's foundation was therefore a consequence of the developments since 1895 and meant to answer the Russian threat. The Triple Intervention, as well as Russia's leasing of Port Arthur and the occupation of Manchuria, had shown that a military confrontation with the Russian Empire was inevitable; Uchida thus felt forced to prepare for war. In the following three years, Uchida and other members of the Amur Society worked to prepare for the war in 1904. These efforts shall now be closely analyzed to discuss the influence of a small secret society on the overall developments towards the outbreak of the war, as well as their role in Japan's victory on the battlefield due to this conflict.

\section{The Amur Society and the Preparation for War}

From the beginning of its foundation, the members of the Amur Society had two priorities: first, to prepare themselves as best as possible for the war (which was supposed to be fought in Korea or Manchuria), and second, to moderate Japan's public opinion of the conflict to ensure that pacifist voices could not influence Japan's foreign policy ${ }^{21}$. Several members of the Gen'yōsha had already been on an expedition in Korea during the 1890 s and were thus familiar with the region. Uchida had also traveled through Siberia and crossed the Kamchatka Peninsula before ${ }^{22}$. Other members of the Society were supposed to do the same to gather military intelligence, draw maps and outline possible enemy positions. These materials were supposedly handed over to the military - unfortunately, there are no military records of this, but later requests for

\footnotetext{
19 The Ten'yūkyō, a sabotage troop was formed in 1894 and its 17 members, one of them Uchida, were sent to Korea to create as much turmoil as possible. On their activities there see HATSUSE, Ryưhei, Dentōteki uyoku, cit., p. 42; SABEY, John Wayne, op. cit., pp. 142-143; UCHIDA, Ryōhei, Nikkan gappō no omoidebanashi, in TANAKA, Takeyuki (ed.), Uchida Ryōhei-ō gojūnensai tsuiboroku, Tōkyō, Kōgyokusha Shuppanbu, 1987, pp. 41-42.

${ }_{20}$ Uchida published his experiences later. UCHIDA, Ryōhei, Kamuchakka Saharin: Fu ohōtsuku engan, Tōkyō, Kokuryūkai, 1904.

${ }^{21}$ In the publications of the 1930 s the society members would claim to have achieved these targets. KUZUU, Yoshihisa, Tōa senkaku shishi kiden, 3 voll., Tōkyō, Hara Shobō, 1966.

${ }_{22}$ Uchida must have had a similar impression like other visitors of the region, who depicted Russia's Far East, and especially Siberia and Manchuria as some kind of borderland without clear borders, why it was assumed suitable for expansion.
} 
member transports to the Japanese navy ${ }^{23}$ or detailed surveillance of the Amur Society by the military point to probable ties between the military and the Society, especially since the members themselves could not have afforded to provide the funds for these operations. There is, in fact, some evidence enforcing the assumption that military funds were channeled through the Foreign Ministry of Japan²4. Yamaza Enjirô (18661914), who headed the office for political issues in the ministry had provided the Gen'yōsha with fundings during the Russo-Japanese War to help establish the Mansh $\bar{u}$ gigun, a paramilitary unit that consisted of members of the society that was supposed to act behind the enemy lines ${ }^{25}$. Since both societies cooperated in these years of the Meiji era pretty close, it can therefore be considered that the Amur Society also used the Foreign Ministry as a source for funding, probably money that was coming from military channels.

Next to embarking on such journeys to gather information about their prospective battlefield, Uchida understood the importance of language. Almost nobody in Japan spoke Russian, which would have been an advantage in a war against Russia ${ }^{26}$. The ability to understand the enemy, question POWs, read information that could be intersected and translate the orders of the opposing army were (and still are) essential, particularly when on the battlefield. To understand the adversary's plan, one must be able to translate their language. Consequently, the Amur Society established a school for the Russian and Chinese language ${ }^{27}$, and the Society's journal, the Kokuryū Kaiho (Amur Bulletin) featured not only articles on East Asian Russia, but also on the Russian language. While the educational value of these measures might be considered minor, the few Japanese who spoke Russian at the time of the war mostly went through that training, especially since most of the members of the Amur Society who participated in the Russo-Japanese War would work as scouts for the Japanese military in Manchuria.

However, the Society went even further. Assuming that the future conflict would take place in northern Korea as well, Uchida and his followers invested money in a

${ }^{23}$ Compare a request by the society for transport of one its members on a ship of the Imperial Navy, Kokuryūkai, Goyōsenbin jōnegai, 25. August 1920, Bōeishō bōei kenkyūjo, Rikugunshônishiju-dainikki, T9-10-49. On the relationship of the society to the military see Iwakura Yoshihisa, 99. Iwakura Yoshihisa, 24. February 1909 Gaimushō gaikō shiryōkan, B-5-2-1721_001.

24 The Japanese Foreign Ministry supposedly provided money for actions of the Gen'yōsha during the Russo-Japanese War, why it can assumed that Uchida might have been able to get financial support for his society through the same channels. ASHIZU, Uzuhiko, Dai-Ajia shugi to Tòyama Mitsuru, vol. 5, Kamakura, Ashizu Jimusho, 2005, pp. 101-105.

25 ASHIZU, Uzuhiko, op. cit., p. 102. For a detailed discussion of Yamazawa's role within Japanese politics see HASEGAWA, Shun, Yamaza Enjiro: tairiku gaiko-no senku, Tokyo-, Jiji Tsūshinsha, 1967.

${ }^{26}$ Russian language capabilities.

${ }_{27}$ SABEY, John Wayne, op. cit., p. 185. 
property on the Korean Peninsula. They purchased two small islands, which would possibly have been used as a depot for military supplies during the war ${ }^{28}$. All these measures appear minor, but considering that the Society probably never had more than a few hundred members, these efforts must be emphasized despite being unable to significantly impact on the war's outcome. Regardless of these investments of money and manpower, the Amur Society and its few members never controlled the preparation process of the war. They were rather a microscopic part of these preparations. More importantly, however, was the attempt to create anti-Russian feelings and stimulate pro-war attitudes throughout Japan.

The Society's publications were an important part of their campaign. They put out the Kokuryū Kaiho, which was prohibited by the government for its anti-Russian emphasis, as well as the journal Kokuryū, which replaced the Kokuryū Kaiho in May 1901, after the second number was so anti-Russian, that the journal was no longer allowed to be published ${ }^{29}$. The articles in these journals were aggressive towards Russia and actively campaigned for a more aggressive Japanese foreign policy. While most of the issues were assumed to have circulated throughout the members themselves, there is no precise data about the number of printed copies. The fact that the government prohibited the issues, however, indicates that the political rulers in the capital were worried about these publications, especially since they could have worsened RussoJapanese relations.

Other publications that had the same effect were Uchida's own writings. In 1901, he published his book Roshia bokokuron (Demise of Russia) ${ }^{30}$, which would also be prohibited by the Japanese government and republished in a less anti-Russian version as Roshiaron (Discourse of Russia) ${ }^{31}$ a few months later. Roshia bokokuron suggested that Japan would lose too much time while waiting for the inevitable conflict with Russia; the Transsiberian Railway would bring countless soldiers to East Asia until it would be too late for Japan to win the war against the Czarist Empire ${ }^{2}$. Following his ideas, the war had to come rather sooner than later, a statement that could have caused diplomatic trouble in 1901. For this reason, the book was prohibited shortly after its publication. Regardless of the government's censorship, the Amur Society and Uchida did not stop trying to influence public opinion.

\footnotetext{
${ }^{28}$ Ibidem, pp. 206-221

29 UCHIDA, Ryōhei, Kōseki gojūnenpu jōkan, in Nihonjin no jiden, vol. 11, Tōkyō, Heibonsha, 1982, p. 279.

30 UCHIDA, Ryōhei, Roshia bokokuron, Tokyo, Daitojuku Shuppanbu, 1977.

${ }^{31}$ UCHIDA, Ko, Roshiaron, Fukuoka, Kokuryūkai, 1901.

$3^{2}$ KATAOKA, Shun, Kokuryū Kurabu, Kokushi Uchida Ryōhei den, Tokyō, Hara Shobō, 1967, p. 745 .
} 
The Society and its members tried to influence politicians and military leaders alike by sending letters or paying visits.33 More important, though, were the public meetings the Societies organized. 34 Prominent speakers, as well as Uchida himself, would inform the crowds about the danger that faced Japan in Manchuria and even Korea at the hands of Russia, whose expansionist goals had been obvious since 1895. Therefore, the only solution was a preventive war, so long as there was some kind of numerical and geographic advantage in doing so. However, as soon as the Russian railway from the European part of the country was fully running, these favourable numbers would vanish almost instantly. Ironically, the arguments regarding this issue resemble the ones for the attack on Pearl Harbor; a supposedly unbeatable enemy was becoming more and more dangerous and the only solution that could lead to a positive outcome the odds of which seemed rather unfavorable - was a quick and unexpected preventive attack. It is unsurprising, then, that Japan's attack in February 1904 was also a surprise attack against the Russian fleet at Port Arthur. Again, it is hard to say how big the impact of the Amur Society and its members had been, but the fact that these gatherings were possible points to the fact that there was a palpable audience for such lectures. It might not have been the majority of the Japanese population, but Uchida and the Society's ideas were at least spread.

That Japan perceived Russia as an enemy is clear, since the war against Russia was supported by the Japanese public and every single victory of Japan's army and navy was celebrated. The war was eventually won and the Amur Society practically lost its reason for existence, but the Peace Treaty of Portsmouth was considered a shame. The Japanese Empire had lost all its battles in Manchuria, and the Russian ships were destroyed or interned in neutral harbors after the Battle of Tsushima. In Portsmouth, however, Foreign Minister Komura Jutarō (1855-1911) was unable to bring home either an indemnity or a territorial gain. The outburst of the population in the Hibiya Park riots has been described by many authors and the members of the Amur Society, who protested the terms of the treaty. They then organized a sub-society that was supposed to organize public lectures against the Treaty of Portsmouth. How long it existed is unclear, but in the very least, some of these meetings were organized in the last months of 1905. The Amur Society itself also continued to exist - the war might have been won

33 It is stated sometimes that Uchida, together with the leader of the Gen'yōsha, Tōyama Mitsuru, visited former Prime Minister and diplomatic emissary to Russia, Itō Hirobumi, to force him to end his negotiations for a peaceful solution with the Czar's government in St. Petersburg.

34 Keishisōkan Takahashi Morio, Tai-Ro mondai kondankai kaisai ni kansuru ken, 28 April 1931, Gaimushō gaikō shiryōkan, B-E-4-9-0-1-007. 
but the danger of Russia did not disappear completely, especially since the United States kept the Czarist Empire as a pawn in East Asia. Uchida and his men therefore still had a purpose and did not dissolve the Society, which existed until 1945. Its agitation in later years, however, would not solely target Russia, but also the United States, who acted in 1905 like St. Petersburg had in 1895.

\section{Conclusion}

Secret Societies are often depicted as mighty institutions that control nation states' policies from behind the curtain. One can say with certainty that this was not the case with the Amur Society. Founded in 1901, it had the sole purpose of preparing for war against Russia, whose government's intervention had cost the Japanese Empire the fruits of victory in 1895. To fulfill their goals, however, the Society lacked the money and manpower. While funded and supported by the military in minor operations to gather intelligence, like cartographic information, the language school of the Society could only provide a rather basic preparation for war. The island the Society had bought in Korea was also useless, since the war did not take place on the Korean Peninsula as anticipated but rather in Manchuria.

Public interest in Russia grew since 1895, and the Amur Society's publications tried to lure in Japanese public opinion towards a preventive war with Russia. Regardless of statements that demanded an immediate strike against the Czarist Empire, not all Japanese were convinced that war was the only solution. Consequently, the government, still interested in diplomatic negotiations, prohibited extreme antiRussian publications by the Society in 1901. The public could therefore solely be reached by lecture series after this point, but the Society had insufficient funding to geographically cover all of Japan. This is why, it must be assumed, that only specific and predominantly right-wing circles participated in such events.

Regardless of the overall negative evaluation of the Amur Society's influence, it has to be considered one of numerous right-wing societies that tried to argue for a more aggressive foreign policy and a preventive war against Russia. The members of the Kokuryūkai were not the only active players in the right-wing circles of Meiji Japan, so other influential figures could surely have been attracted by their message. However, this is difficult to prove, and as far as it can be said with regard to the available sources, there was neither any direct contact to nor the slightest form of control over any prolific contemporary Japanese politicians. 
When the war eventually broke out in 1904, the members of the Kokuryūkai must have been happy - their hard work would provide a mosaic for Japan's military successes. That the depiction of the share of responsibility for these successes would be overemphasized in most of the later publications of the Amur Society led to the idea that members of this secret society had forced Japan go to war. Such statements, however, rather belong to a world of conspiracy theories than to one of historically provable fact. 


\section{* The author}

Frank Jacob is Assistant Professor of World History at the City University of New York (QCC) and the recipient of the CUNY Academy's Henry Wasser Award for Outstanding Assistant Professors in 2016. He received his PhD in Japanese Studies from Erlangen University in 2012 and teaches at CUNY since 2014. His major research foci are Modern Japanese History, Military History, and the History of Tobacco. He has published more than 20 books and numerous articles and book chapters. His latest books include: Tsushima 1905 Ostasiens Trafalgar (Paderborn, Schöning, 2017), The Russo-Japanese War and its Shaping of the 2oth Century (London, Routledge, 2017) and The Military Revolution in Early Modern Europe: A Revision (London, Palgrave, 2016, co-authored with Gilmar Visoni-Alonzo).

URL: < http://www.studistorici.com/progett/autori/\#Jacob >

\section{Per citare questo articolo:}

JACOB, Frank, «Secret Societies in Japan and Preparation for the Russo-Japanese War (1904-1905)», Diacronie. Studi di Storia Contemporanea : La voce del silenzio: intelligence, spionaggio e conflitto nel XX secolo, 29/12/2016, URL:< http://www.studistorici.com/2016/12/29/jacob_numero_28/ >

Diacronie Studi di Storia Contemporanea $\vartheta$ www.diacronie.it

Risorsa digitale indipendente a carattere storiografico. Uscita trimestrale. redazione.diacronie@hotmail.it

Comitato di redazione: Jacopo Bassi - Luca Bufarale - Antonio César Moreno Cantano - Deborah Paci - Fausto Pietrancosta - Alessandro Salvador - Matteo Tomasoni - Luca Zuccolo

Diritti: gli articoli di Diacronie. Studi di Storia Contemporanea sono pubblicati sotto licenza Creative Commons 3.0. Possono essere riprodotti e modificati a patto di indicare eventuali modifiche dei contenuti, di riconoscere la paternità dell'opera e di condividerla allo stesso modo. La citazione di estratti è comunque sempre autorizzata, nei limiti previsti dalla legge. 